Eur. J. Clin. Chem. Clin. Biochem.

Vol. 32, 1994, pp. 779-787

(c) 1994 Walter de Gruyter \& Co. Berlin · New York

\title{
Tissue Polypeptide Antigen and Tissue Polypeptide Specific Antigen in Primary Breast Cancer Evaluation in Serum and Tumour Tissue
}

By M. Gion ${ }^{1}$, R. Mione ${ }^{1}$, P. Barioli ${ }^{1}$, P. Sartorello ${ }^{1}$ and G. Capitanio ${ }^{2}$

1 Centro Regionale per lo Studio degli Indicatori Biochimici di Tumore, Ospedale Civile, Venezia, Italy

2 Divisione di Anatomia Patologica, Ospedale Civile, Venezia, Italy

(Received March 29/July 7, 1994)

Summary: Tissue polypeptide antigen, measured by both a polyclonal antibody (TPA IRMA Prolifigen ${ }^{\circledR}$ ) and a monoclonal antibody prototype kit (TPA-M IRMA Prolifigen ${ }^{\circledR}$ ), and the tissue polypeptide specific antigen were evaluated. The markers were measured in 266 serum samples and in 291 tumour cytosols from patients with primary breast cancer. The three markers were available in matched pairs of both serum and cytosol from the same patient in 144 cases.

Diagnostic sensitivity of serum levels of the three markers was not significantly different when using cut-off values calculated on the basis of healthy subjects.

In the cytosol, tissue polypeptide antigen (TPA IRMA), tissue polypeptide antigen (TPA-M IRMA) and tissue polypeptide specific antigen were significantly correlated with steroid receptor status, while their serum levels were not.

Cytosol and serum levels of the three markers were not significantly associated. All three were significantly correlated both in serum and in cytosol. The association was closer between tissue polypeptide antigen (TPA IRMA) and tissue polypeptide antigen (TPA-M IRMA) than between each of these two markers and tissue polypeptide specific antigen.

From these findings we draw the following conclusions:

1. Tissue polypeptide specific antigen (TPA IRMA) and tissue polypeptide antigen (TPA-M IRMA) probably províde superimposable information both in serum and in cytosol;

2. Tissue polypeptide specific antigen and tissue polypeptide antigen (TPA IRMA) or tissue polypeptide antigen (TPA-M IRMA), although closely associated, probably measure in part different cytokeratins. Therefore, they should not be considered interchangeable in individual patients;

3. The determination of the markers in serum and in cytosol provides different information concerning the tumour phenotype.

\section{Introduction}

Keratin is one of the five classes of intermediate filaments that have a major role as a component of the cytoskeleton of epithelial tissues (1).

The keratin filament family consists of 20 distinct polypeptides that can be subdivided into 2 major groups: the first is represented by polypeptides with a relatively high molecular mass and more acidic pI (types 1 to 8), the second by those with a relatively low molecular mass and a more basic pI (types 12 to 20) (2). Usually, a basic and an acidic polypeptide are associated in a heterodim- 
eric keratin filament (3). Cytokeratins $8 / 18$ and $8 / 19$ are frequently expressed in several simple epithelia and in the malignancies that are derived from these $(4-6)$.

Although cytokeratins are virtually insoluble (7), several soluble fragments are released by the tissue, so that it is possible to assay cytokeratin-related biochemical indicators in body fluids.

The first marker of this group was identified and described by Björklund \& Björklund and named tissue polypeptide antigen (TPA IRMA) (8). Tissue polypeptide antigen (TPA IRMA) was elevated in the blood of patients affected by several types of tumours and was related to poor prognosis in some malignancies $(8-13)$.

In breast cancer, higher serum tissue polypeptide antigen (TPA IRMA) levels were correlated with a poor prognosis (13). Conversely, a high cytosol tissue polypeptide antigen (TPA IRMA) level was shown to be a powerful, independent, favourable prognostic indicator (14-16).

New information was obtained with the aid of hybridoma technology, which led to the development of several monoclonal antibodies against tissue polypeptide antigen. They were used both for molecular studies (17, 18) and to devise different assay kits to measure tissue polypeptide antigen in body fluids. Biochemical studies demonstrated that the different monoclonal antibodies used in different commercial assay kits recognize the cytokeratins 8,18 and 19 in a different manner (18). A monoclonal antibody assay kit, named tissue polypeptide specific antigen, was devised by BEKI Diagnostic. It has been claimed that the antibody of the tissue polypeptide specific antigen assay kit recognizes a specific tissue polypeptide antigen epitope (M3) that is probably different from cytokeratins $(19,20)$.

However, recent work by Bodenmüller et al. (18) has shown that antibodies used in the tissue polypeptide antigen (TPA IRMA) assay strongly react with cytokeratins 8 and 19, while tissue polypeptide specific antigen antibody strongly reacts with cytokeratin 18 , but very weakly with cytokeratin 8 in the immunoblot assay. As a consequence, tissue polypeptide antigen (TPA IRMA) antibodies recognize the combination cytokeratin $8 / 18$ and cytokeratin $8 / 19$, while tissue polypeptide specific antigen antibodies preferably recognize the combination cytokeratin $8 / 18$. From these data it can be expected that tissue polypeptide antigen (TPA IRMA) assay recognizes a broader spectrum of patients than tissue polypeptide specific antigen, as cytokeratin 18 can also be associated with other acidic keratins. In accordance with these findings, Stieber et al. (21) have reported clearly different sensitivity values of tissue polypeptide antigen (TPA IRMA) and tissue polypeptide specific antigen assays in patients with lung cancer.
In the present investigation we evaluated the tissue polypeptide antigen (TPA IRMA) assay, a new monoclonal antibody-based tissue polypeptide antigen assay (TPAM IRMA), and tissue polypeptide specific antigen in serum and cytosol from primary breast cancer, addressing the following items:

1. to evaluate the association between the markers and other disease indicators (tumour size, nodal status, histological type, tumour grade, steroid receptors);

2. to evaluate whether the markers show similar or different association patterns with other disease indicators when measured in serum and in cytosol;

3. to evaluate the association among the markers, in order to assess whether they can be expected to provide redundant or additional information.

\section{Materials and Methods}

Serum and tumour tissue samples were collected from 342 patients with primary breast cancer. Serum samples from 76 apparently healthy subjects were also evaluated. Statistical evaluation was restricted to cases in which all the three markers had been assayed, i. e. 266 for serum, 291 for cytosol and 144 for matched pairs of both serum and cytosol from the same patient. Serum samples were collected on the day of the operation before the administration of any drug. Tissue samples of primary breast cancer were collected freshly from the operating room, kept on ice and stored within 30 minutes in liquid nitrogen. Frozen tissue samples were pulverized using a microdismembrator and suspended in phosphate buffer (tissue/buffer ratio ranging from $1: 8$ to $1: 20$ ). The homogenate was then centrifuged for 1 hour at $100000 \mathrm{~g}$ and the supernatant (cytosol) used for biochemical assays.

Tissue polypeptide antigen was measured using both the polyclonal (TPA IRMA Prolifigen ${ }^{\circledR}$ ) and a monoclonal antibody-based twosite sandwich solid phase immunoradiometric assay kit (TPA-M IRMA Prolifigen ${ }^{\circledR}$ ), kindly provided by Sangtec Medical, Bromma, Sweden. The TPA-M IRMA Prolifigen ${ }^{\circledR}$ used at the time of the investigation was still a prototype version.

Tissue polypeptide specific antigen (TPS) was measured by the two-site sandwich immunoradiometric assay kindly supplied by BEKI Diagnostic (Bromma, Sweden). The assays were carried out according to the manufacturer's instructions. The performance characteristics of the assays were evaluated according to standard criteria $(22,23)$. Both inter = and intra-assay precision were assessed by measuring pools of human sera at low, intermediate and high antigen concentrations. The sensitivity was expressed as the dose corresponding to the counts per minute resulting from the mean plus 3 standard deviations of the " 0 " standard calibrator. The accuracy was evaluated with the dilution test, which was carried out by using phosphate buffer containing $3 \mathrm{~g} / \mathrm{l}$ of bovine serum albumin. This buffer had been previously validated for the tissue polypeptide antigen (TPA IRMA) assay in cytosol samples (14). The results of the evaluation of performance characteristics are summarized in table 1.

Oestrogen and progesterone receptors were measured using a radioligand binding assay set up according to the EORTC criteria (24). The conventional value of $10 \mathrm{fmol} / \mathrm{mg}$ of cytosol protein was used for both oestrogen receptors and progesterone receptors to categorize tumour samples as positipe or negative. 
Tab. 1 Performance characteristics of tissue polypeptide antigen (TPA IRMA), tissue polypeptide antigen (TPA-M IRMA) and tissue polypeptide specific antigen.

\begin{tabular}{|c|c|c|c|c|c|c|}
\hline & \multicolumn{3}{|l|}{ Precision } & \multirow{2}{*}{$\begin{array}{l}\text { Analytical } \\
\text { sensitivity }\end{array}$} & \multicolumn{2}{|l|}{ Accuracy } \\
\hline & $\begin{array}{l}\text { Antigen } \\
\text { concentration } \\
\text { (U/1) } \\
\text { (mean) }\end{array}$ & $\begin{array}{l}\text { Intra- } \\
\text { assay } \\
\mathrm{CV} \\
(\%)\end{array}$ & $\begin{array}{l}\text { Inter- } \\
\text { assay } \\
\mathrm{CV} \\
(\%)\end{array}$ & & $\begin{array}{l}\text { Evaluated } \\
\text { dilution } \\
\text { range }\end{array}$ & $\begin{array}{l}\text { Recovery } \\
\text { mean } \pm \text { SD } \\
(\%)\end{array}$ \\
\hline $\begin{array}{l}\text { Tissue polypeptide antigen } \\
\text { (TPA IRMA) }\end{array}$ & $\begin{array}{r}70 \\
194 \\
1099\end{array}$ & $\begin{array}{l}7.8 \\
7.9 \\
6.4\end{array}$ & $\begin{array}{l}8.8 \\
9.3 \\
9.1\end{array}$ & $12.5 \mathrm{U} / 1$ & $1: 11$ to $1: 40581$ & $98 \pm 4$ \\
\hline $\begin{array}{l}\text { Tissue polypeptide antigen } \\
\text { (TPA-M IRMA) }\end{array}$ & $\begin{array}{r}59 \\
198 \\
1056\end{array}$ & $\begin{array}{l}8.0 \\
7.6 \\
8.1\end{array}$ & $\begin{array}{r}11.3 \\
8.7 \\
12.6\end{array}$ & $10 \mathrm{U} / \mathrm{I}$ & $1: 50$ to $1: 8000$ & $102 \pm 5$ \\
\hline $\begin{array}{l}\text { Tissue polypeptide } \\
\text { specific antigen }\end{array}$ & $\begin{array}{r}89 \\
208 \\
1188\end{array}$ & $\begin{array}{l}5.3 \\
6.0 \\
4.6\end{array}$ & $\begin{array}{l}7.1 \\
7.4 \\
6.1\end{array}$ & $12.5 \mathrm{U} / 1$ & $1: 5$ to $1: 40581$ & $99 \pm 8$ \\
\hline
\end{tabular}

The cytosol protein concentration was measured using the Coomassie Brilliant Blue Colorimetric assay (Bio-Rad Laboratories ECS Division, Anaheim, CA) (25).

Statistical analysis was carried out using the Kruskal-Wallis test and linear regression analysis.

\section{Results}

Both serum and cytosol levels of the three markers are summarized in table 2 . The diagnostic sensitivity of serum marker levels was evaluated at $95 \%$ and $99 \%$ specificity with reference to a group of 76 healthy subjects. The figures were respectively $25.3 \%$ and $17.4 \%$ for tissue polypeptide antigen (TPA IRMA), $25.9 \%$ and $18.4 \%$ for tissue polypeptide antigen (TPA-M IRMA) and $28.4 \%$ and $18.3 \%$ for tissue polypeptide specific antigen. Serum concentrations of tissue polypeptide antigen (TPA IRMA) and tissue polypeptide specific antigen showed similar values, while tissue polypeptide antigen (TPA-M IRMA) was lower. In the cytosol, tissue polypeptide antigen (TPA-M IRMA) showed the highest concentration and tissue polypeptide specific antigen the lowest, while tissue polypeptide antigen (TPA IRMA) presented intermediate levels. These comparisons should however be considered artifactual and poorly informative, since the marker concentrations are expressed in arbitrary units. Of major interest are the ratios between serum and cytosol levels for each marker, since in this case the absolute numerical value of the concentrations is not relevant. The concentrations of the three markers were higher in cytosol than in serum. However, the cytosol to serum ratio was significantly $(p<0.01)$ different between the three markers, being 22 for tissue polypeptide antigen (TPA-M IRMA), 8 for tissue polypeptide antigen (TPA IRMA) and 4 for tissue polypeptide specific antigen.

\section{Relationship with other quantities and} indicators

Serum levels of tissue polypeptide antigen (TPA-M IRMA) were significantly higher in $\mathrm{N}+$ than in $\mathrm{N}-$ cases (Kruskal-Wallis test $\mathrm{p}=0.038$ ) and tended to be higher in larger tumours $(\varnothing>2 \mathrm{~cm})$ than in smaller ones $(\varnothing<2 \mathrm{~cm})$ (Kruskal-Wallis test $\mathrm{p}=0.054)$. Although a similar trend was found for tissue polypeptide antigen (TPA IRMA) and tissue polypeptide specific antigen in relation to tumour size, differences were not significant in the case of these two latter markers. Also, tissue polypeptide antigen (TPA IRMA) and tissue polypeptide specific antigen showed no differences at all between $\mathrm{N}+$ and $\mathrm{N}-$ cases.

Cytosol levels of the three markers did not show any relation with either nodal status or tumour size.

Serum and cytosol levels of the three markers did not show significant variations related to histological type or tumour grade (data not shown).

In general, the cytosol levels of the three markers were higher in cases in which oestrogen receptors and progesterone receptors were expressed (fig. 1), while their serum levels were not associated with steroid receptor status. Cytosol tissue polypeptide antigen (TPA IRMA) was significantly higher in oestrogen receptor positive tumours than in oestrogen receptor negative tumours, and higher in progesterone receptor positive tumours than in progesterone receptor negative tumours (Kruskal-Wallis test $\mathrm{p}<0.0001$ for both). The same behaviour, although at a lower significance level for progesterone receptor, was found for tissue polypeptide antigen (TPA-M IRMA) (Kruskal-Wallis test $p<0.0001$ for oestrogen receptors, $p=0.0120$ for progesterone receptors) and tissue polypeptide specific antigen 
Tab. 2 Tissue polypeptide antigen (TPA IRMA), tissue polypeptide antigen (TPA-M IRMA) and tissue polypeptide specific antigen values in biological samples from patients with breast cancer.

\begin{tabular}{|c|c|c|c|c|c|}
\hline \multicolumn{3}{|l|}{ Serum } & \multicolumn{3}{|l|}{ Cytosol } \\
\hline $\begin{array}{l}\text { Tissue } \\
\text { polypeptide } \\
\text { antigen } \\
\text { (TPA IRMA) }\end{array}$ & $\begin{array}{l}\text { Tissue } \\
\text { polypeptide } \\
\text { antigen } \\
\text { (TPA-M IRMA) }\end{array}$ & $\begin{array}{l}\text { Tissue } \\
\text { polypeptide } \\
\text { specific } \\
\text { antigen }\end{array}$ & $\begin{array}{l}\text { Tissue } \\
\text { polypeptide } \\
\text { antigen } \\
\text { (TPA IRMA) }\end{array}$ & $\begin{array}{l}\text { Tissue } \\
\text { polypeptide } \\
\text { antigen } \\
\text { (TPA-M IRMA) }\end{array}$ & $\begin{array}{l}\text { Tissue } \\
\text { polypeptide } \\
\text { specific } \\
\text { antigen }\end{array}$ \\
\hline
\end{tabular}

\section{Overall}

Cases $(\mathrm{N})$

Median (U/I)

Interquartile $(\mathrm{U} / \mathrm{l})$

266
54
$36-83$

266
30
$13-49$

266
57
$32-107$

Cases $(\mathbb{N})$

Median (U/l)

Interquartile (U/l)

$N+$

Cases (N)

Median (U/I)

Interquartile (U/l)

$\varnothing<2 \mathrm{~cm}$

Cases (N)

Median (U/I)

Interquartile (U/1)

Cases $(\mathrm{N})$

Median (U/l)

Interquartile (U/1)
291
494

$253-783$

139
530
$284-889$

692

340

291
648

$335-1173$

291

245

$110-509$

125

443

$215-782$

111

531

$259-886$
153

454

$252-788$

\section{5}

623

314-1089

221

$88-512$

139

269

$118=542$

25 $\varnothing>2 \mathrm{~cm}$
140

24
$11-41$

140
52
$33-84$

101
55
$38-76$

$\begin{array}{ll}92 & 92 \\ 49 & 24 \\ 32-74 & 10-41\end{array}$

\section{0}

55

$32-100$

$\begin{array}{lc}101 & 101 \\ 33 & 56 \\ 14-53 & 31-110\end{array}$

10-41

$\begin{array}{ll}111 & 111 \\ 57 & 33 \\ 38-88 & 15-50\end{array}$

$31-110$

92
50
$32-89$

111
63
$34-118$

$\mathrm{N}^{-}$without axillary lymphnode metastases

$\mathrm{N}^{+}$with axillary lymphnode metästases

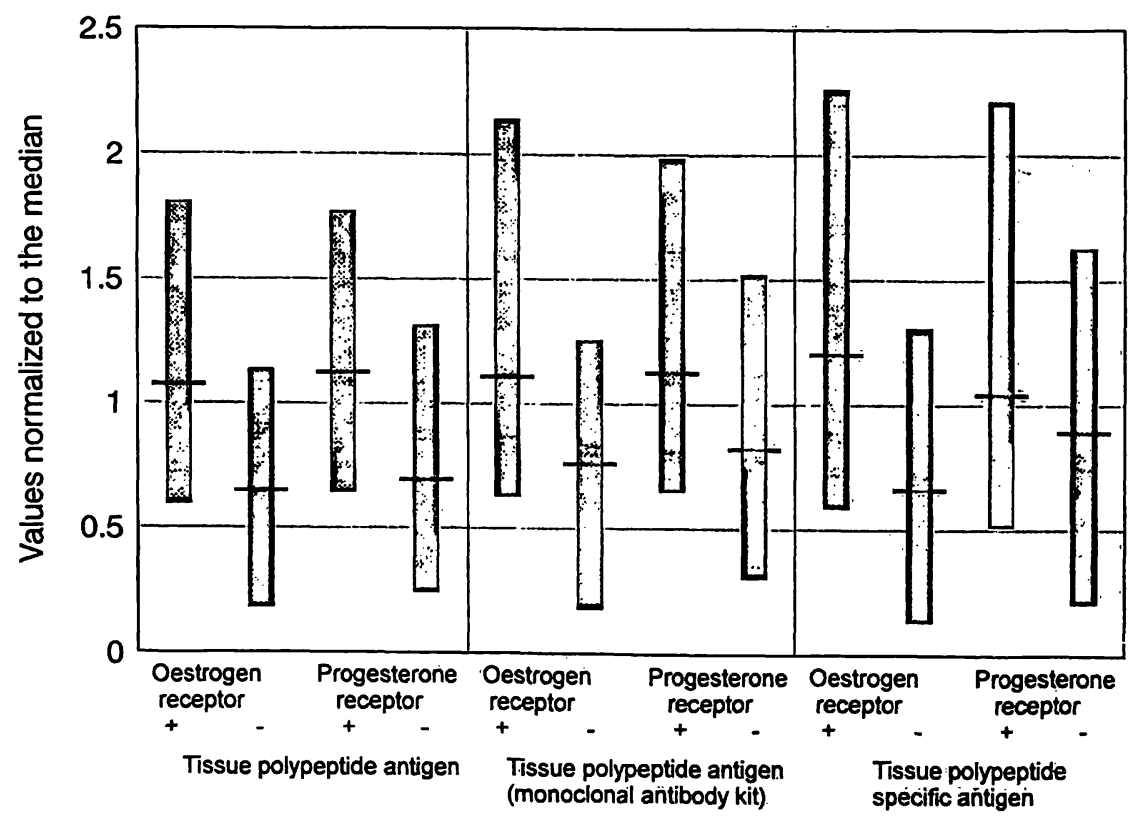

Fig. 1 Relationship between the marker cytosol levels and steroid receptor status. Vertical bars represent the interquartile range of tumour marker levels. The horizontal line is taken as the median value. The positive/negative threshold level was $10 \mathrm{fmol} / \mathrm{mg}$ of cytosol protein for both oestrogen and progesterone receptors. The marker levels were normalized with reference to the median value of each marker.

(Kruskal-Wallis test $\mathrm{p}<0.0001$ for oestrogen receptors, by the linear regression analysis between the logarithms $\mathrm{p}=0.0011$ for progesterone receptors). The association of the concentrations of both tumour markers and between the markers and receptor status was confirmed oestrogen receptor or progeșțerone receptor (tab. 3). 
Tab. 3 Association between the cytosol levels of tumor markers and receptor status. Results of linear regression analysis between logarithms $($ ln $)$ of values.

\begin{tabular}{|c|c|c|c|}
\hline & $\begin{array}{l}\text { Tissue } \\
\text { polypeptide } \\
\text { antigen } \\
\text { (TPA IRMA) }\end{array}$ & $\begin{array}{l}\text { Tissue } \\
\text { polypeptide } \\
\text { antigen } \\
\text { (TPA-M IRMA) }\end{array}$ & $\begin{array}{l}\text { Tissue } \\
\text { polypeptide } \\
\text { specific } \\
\text { antigen }\end{array}$ \\
\hline \multicolumn{4}{|c|}{ Oestrogen receptors: } \\
\hline $\mathrm{N}$ & 282 & 282 & 282 \\
\hline$r$ & 0.286 & 0.285 & 0.277 \\
\hline $\mathrm{p}$ & $<0.001$ & $<0.001$ & $<0.001$ \\
\hline \multicolumn{4}{|c|}{ Progesterone receptors: } \\
\hline $\mathrm{N}$ & 286 & 286 & 286 \\
\hline$r$ & 0.267 & 0.210 & 0.206 \\
\hline $\mathrm{p}$ & $<0.001$ & $<0.001$ & $<0.001$ \\
\hline
\end{tabular}

These findings confirm a preliminary report of our group, in which we found a significant association between oestrogen receptor and cytosol tissue polypeptide antigen (26). They are also in agreement with previous findings of our group that demonstrate a significant association between higher tissue polypeptide antigen cytosol levels and a better prognosis (14-16).

\section{Association among the three markers}

The three markers were significantly associated both in serum (fig. 2) and in the cytosol (fig. 3). The association pattern was similar using both data and logarithm of data, the latter being shown in the figures. The marker levels were more closely associated in the cytosol than in serum. These findings could suggest either differences of distribution and metabolism, or a different release by the tumour of the three markers, and they support a possible difference among the molecules recognized by the three different așșay kits.

\section{Relationship between cytosol and serum}

Figure 4 shows the regression analysis between serum and cytosol levels of the three markers. According to the data, as well as the logarithms of data, the levels of the marker in the two compartments were not associated, although a non-significant trend toward an negative association between serum and cytosol tissue polypeptide antigen (TPA IRMA) was found. These findings clearly indicate that the marker serum level is probably affected by several variables other than production and release by the tumour, and emphasize that it is difficult to predict the usefulness of the determination of markers in the blood from their concentration in the cytosol. On the other hand, the determination of the marker in the two biological fluids could possibly provide different information.

\section{Discussion}

The number of tumour markers used in the clinical practice should be restricted, in order to avoid redundant information and to reduce unnecessary costs. This problem arises when several tumour markers belonging to the same molecular family are available, as in the case of cytokeratin related biochemical indicators, for which several commercially available kits have been recently developed. Indeed, different assay kits could provide different clinical information in some individual patients. An unanswered question is whether this anecdotal benefit may justify the cost of performing routinely a panel of cytokeratin family markers in any patient. The same item has been raised in the case of mucin markers for breast cancer. Indeed, general consensus was reached on the possibility of using a single mucin marker in this latter malignancy (27).

In the case of the cytokeratin-related markers, two diverse opinions exist. On the one hand, Björklund et al. consider that tissue polypeptide specific antigen recognizes an antigen associated with proliferation which is not a cytokeratin $(19,20)$. Although they admit a possible cross-reactivity of tissue polypeptide specific antigen with cytokeratins, even with a lower affinity, they suggest that tissue polypeptide antigen (TPA IRMA) and tissue polypeptide specific antigen provide different biological information, the first being related to cell death and the second to cell proliferation (20). On the other hand, Bodenmüller et al. demonstrated that the antibody used in the tissue polypeptide specific antigen assay kit recognizes cytokeratin 18 , which led them to include tissue polypeptide specific antigen among the cytokeratin family of tumour markers (18). The problem should be evaluated from the point of view of the clinical application, to assess whether the markers provide similar or different information. This point is of relevance in breast cancer, since both serum and cytosol tissue polypeptide antigen (TPA IRMA) levels showed a clear clinical usefulness $(10,13-16)$.

Tissue polypeptide antigen and tissue polypeptide specific antigen were therefore compared in a group of patients with breast cancer, which was large enough for statistical evaluation. Both the old polyclonal antibodybased tissue polypeptide antigen (TPA IRMA), which had been thoroughly studied in breast cancer, and the more recently available monoclonal antibody-based tissue polypeptide antigen (TPA-M IRMA) were assayed. Indeed, the latter tissue polypeptide antigen (TPA-M IRMA) assay presents two advantages in comparison to the old one: firstly, the cytokeratins recognized by the monoclonal antibody are well known, and secondly, the 

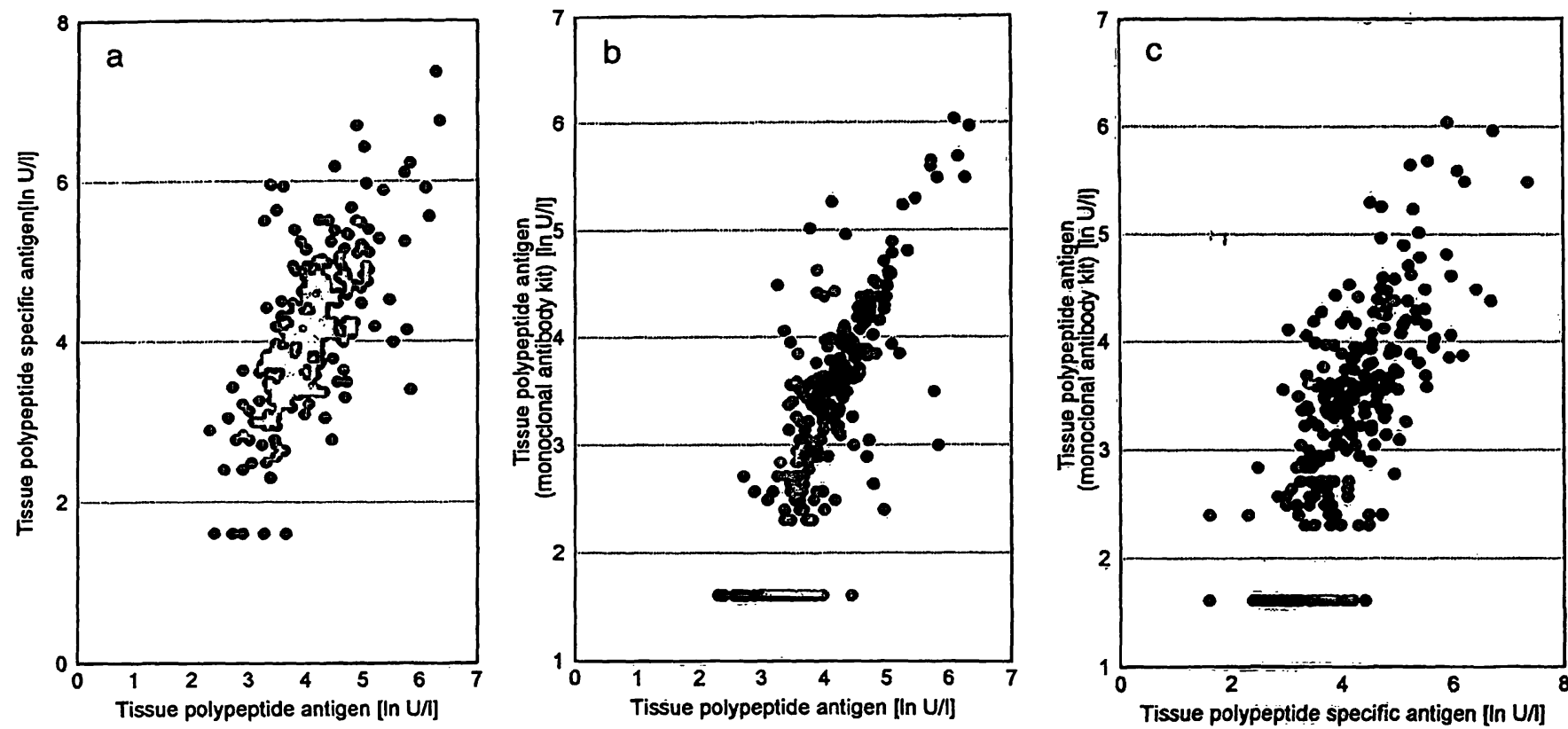

Fig. 2 Correlation among serum levels of the three markers (linear regression analysis using $\ln$ of data).

Linear regression analysis:

Tissue polypeptide antigen (TPA IRMA) vs tissue polypeptide specific antigen: $y=0.364+0.919 x ; n=266 ; r=0.684 ; p<0.001$.

Tissue polypeptide antigen (TPA IRMA) vs tissue polypeptide antigen (TPA-M IRMA): $\mathrm{y}=-1.50+1.175 \mathrm{x} ; \mathrm{n}=266 ; \mathrm{r}=0.788$; $\mathrm{p}<0.001$.

Tissue polypeptide specific antigen vs tissue polypeptide antigen (TPA-M IRMA): $\mathrm{y}=0.037+0.803 \mathrm{x} ; \mathrm{n}=266 ; \mathrm{r}=0.731$ $\mathrm{p}<0.001$.
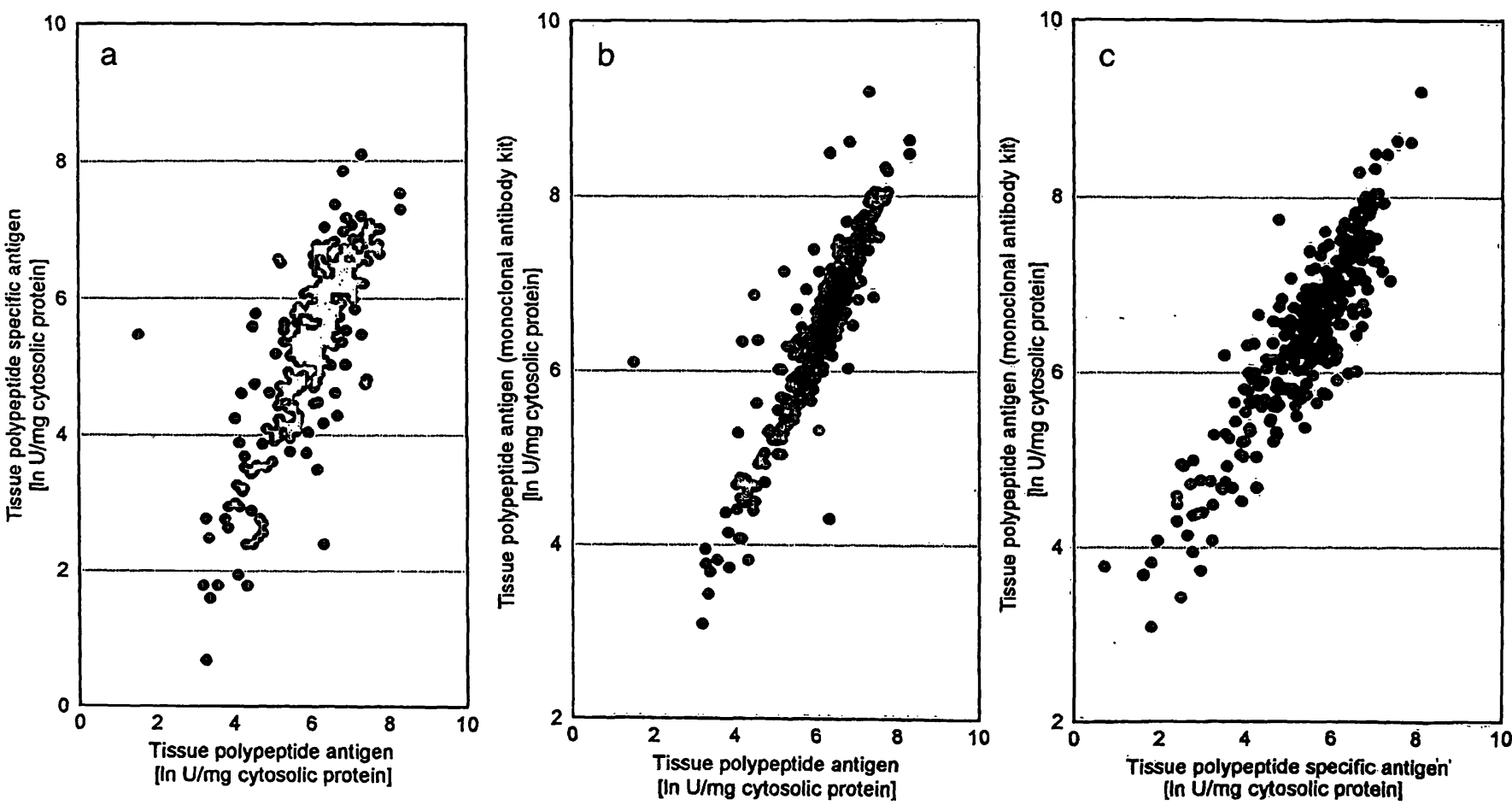

Fig. 3 Correlation among cytosol levels of the three markers (linear regression analysis using In of data).

Linear regression analysis:

Tissue polypeptide antigen (TPA IRMA) vs tissue polypeptide specific antigen: $\mathrm{y}=-0.786+1.014 x ; \mathrm{n}=291 ; \mathrm{r}=0.810$; $\mathrm{p}<0.001$.

Tissue polypeptide antigen (TPA IRMA) vs tissue polypeptide antigen (TPA-M IRMA): $y=0.933+0.906 x ; n=291 ; r=0.886$; $\mathrm{p}<0.001$.

Tissue polypeptide specific antigen vs tissue polypeptide antigen (TPA-M IRMA): $\mathrm{y}=2.50+0.731 \mathrm{x} ; \mathrm{n}=291 ; \mathrm{r}=0.895$ $\mathrm{p}<0.001$.

use of monoclonal antibodies should provide more reliable, stable and reproducible assay systems.
The results of the present investigation showed that tissue polypeptide antigen (TPA IRMA), tissue polypeptide antigen (TPA-M IRMA) and tissue polypeptide spe- 

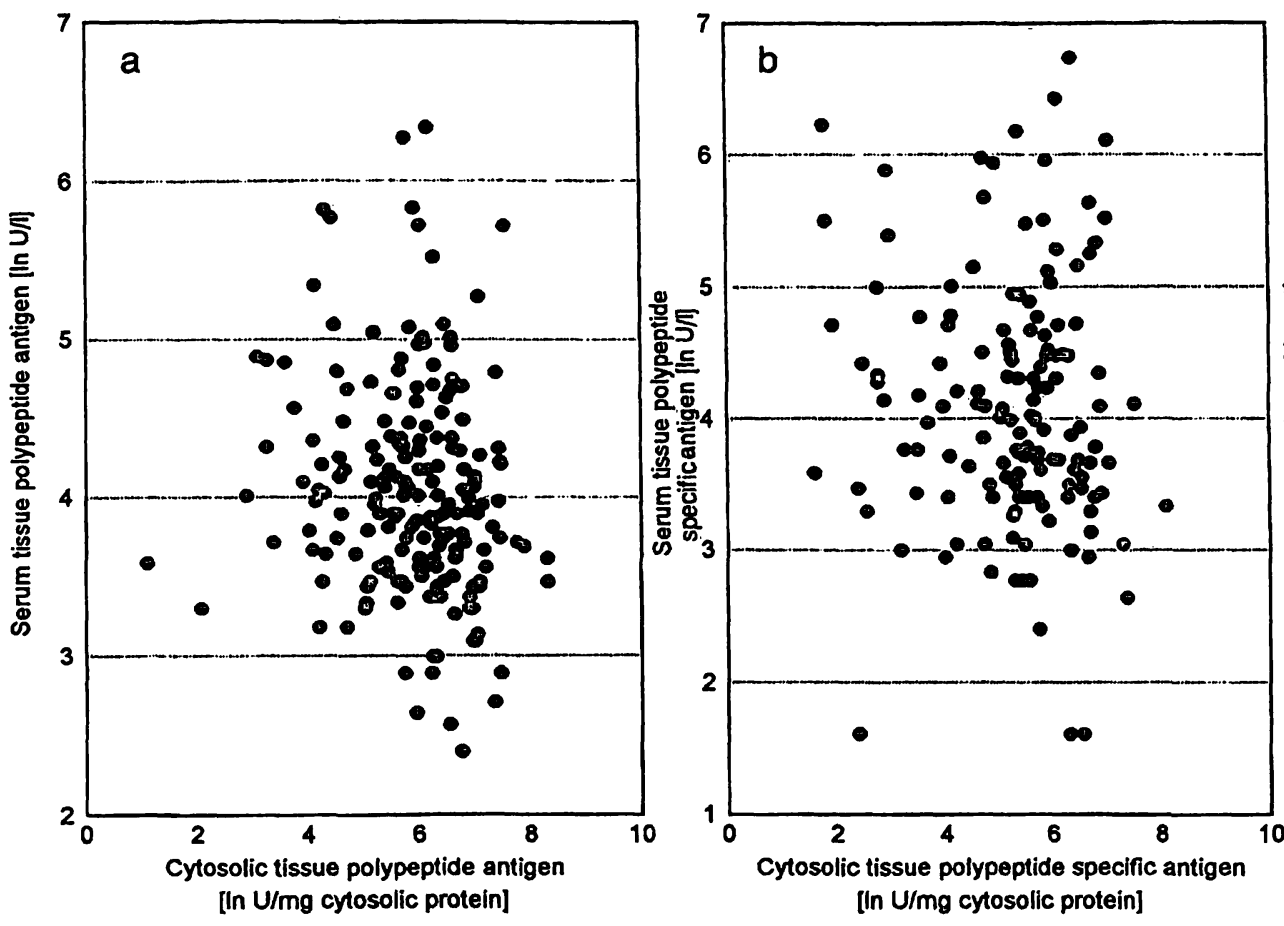

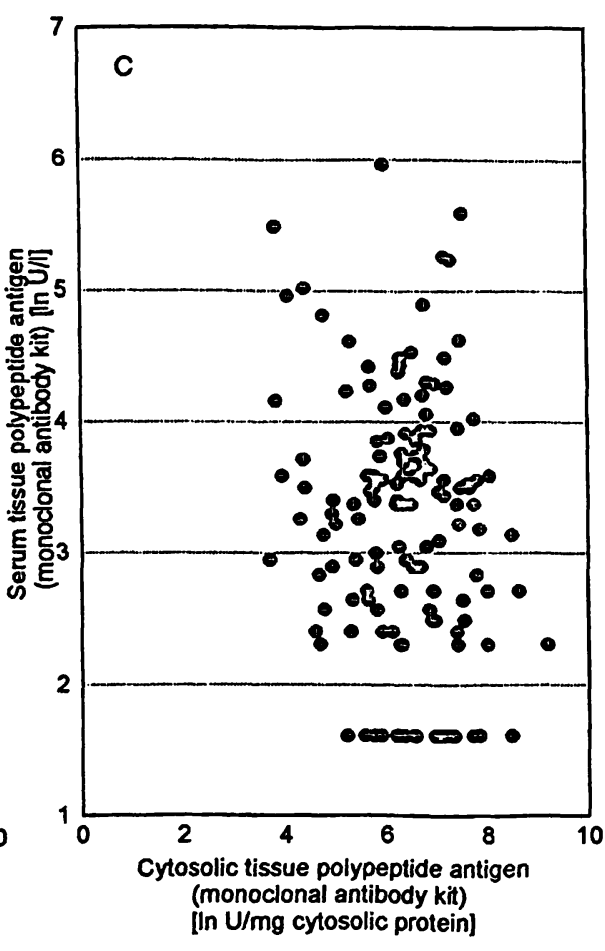

Fig. 4 Correlation between cytosol and serum levels of each marker (regression analysis using $\ln$ of data).

Linear regression analysis:

Cytosolic tissue polypeptide antigen (TPA IRMA) vs serum tissue polypeptide antigen (TPA IRMA): $y=4.806-0.134 x ; n=144$; $\mathrm{r}=-0.205 ; \mathrm{p}=0.014$.

cific antigen are well correlated both in serum and in cytosol. The association is closer between tissue polypeptide antigen (TPA-M IRMA) and tissue polypeptide antigen (TPA IRMA) than between the two tissue polypeptide antigen and tissue polypeptide specific antigen, as could have been expected on the basis of the study by Bodenmüller et al. on the reactivity of monoclonal antibodies in the assay kits (18). Although a good correlation is never proof that the same substance is being measured, it should be noted that tissue polypeptide specific antigen measures something that has a close direct relationship with tissue polypeptide antigen. The similar association between the three markers and steroid receptors status, as well as with the $\left[{ }^{3} \mathrm{H}\right]$ thymidine labelling index, as we demonstrated in a previous study (28), strongly suggests that tissue polypeptide specific antigen and tissue polypeptide antigen have similar meaning with reference to other biological features of the tumour. Accordingly, the diagnostic sensitivity of the serum levels of the three markers is remarkably similar.

The association between tissue polypeptide antigen (TPA-M IRMA) and tumour burden ( $\mathrm{N}$ and $\mathrm{T}$ ) is too weak to represent a clinically significant difference between tissue polypeptide antigen (TPA-M IRMA) and both tissue polypeptide antigen (TPA IRMA) and tissue polypeptide specific antigen.
Cytosolic tissue polypeptide specific antigen vs serum tissue polypeptide specific antigen: $\mathrm{y}=4.394-0.057 \mathrm{x} ; \mathrm{n}=144$; $r=-0.080 ; p=0.337$.

Cytosolic tissue polypeptide antigen (TPA-M IRMA) vs serum tissue polypeptide antigen (TPA-M IRMA): $y=4.264-0.162 \mathrm{x}$; $\mathrm{n}=144 ; \mathrm{r}=-0.176 ; \mathrm{p}=0.034$.

Nevertheless, the fact that the association between tissue polypeptide antigen and tissue polypeptide specific antigen is more significant in cytosol than in serum, suggests that factors responsible for the circulating levels of the marker (such as the rate of release by the tumour, the dilution in body fluids, metabolism and excretion) may affect the three markers differently, thus supporting a possible molecular difference between them. The different cytosol-to-serum ratios of the three markers also support this hypothesis.

Another relevant point is the lack of correlation between serum and cytosol levels of each marker when measured in the same patients. This could be due to the effects of dilution by body fluids, metabolism and excretion on the serum level of the marker when the tumour mass producing the marker is limited, which is the case in patients bearing primary malignancies. However, apart from any possible interpretation, it leads to two practical consequences:

1. the determination of the markers in the two compartments can provide different information and

2. the determination of the marker in the cytosol is not predictive of its serum levels, and vice versa.

From the findings of the present investigation, we can draw the following conclusions: 
1. tissue polypeptide antigen (TPA IRMA) and tissue polypeptide antigen (TPA-M IRMA) provide closely associated results; although their absolute values are in part different, they are expected to provide overlapping clinical information;

2. tissue polypeptide specific antigen is associated with tissue polypeptide antigen (TPA-M IRMA) and tissue polypeptide antigen (TPA IRMA); the relationship between the tumour markers and other biological quantities are in the same direction. Even accepting that tissue polypeptide specific antigen could measure a tissue polypeptide antigen-specific epitope, it is evident that it also measures cytokeratin fragments in a quantitatively significant manner;

3. from a practical point of view, cytosol and serum should be considered independent biological fluids as far as tissue polypeptide antigen (TPA IRMA) and tissue polypeptide specific antigen determinations are concerned;

4. the direct association between cytosol levels of tissue polypeptide antigen (TPA IRMA), tissue polypeptide antigen (TPA-M IRMA), and tissue polypeptide specific antigen and receptor status represents a potential association between the markers and prognosis, in agreement with previous findings of our group concerning cytosolic tissue polypeptide antigen (14-16).

The relationship between the three markers and the clinical outcome of the patients is the goal of an ongoing study which should define any actual prognostic role of tissue polypeptide antigen (TPA-M IRMA) and tissue polypeptide specific antigen.

\section{Acknowledgement}

The present investigation was financially supported in part by the Regione Veneto, Italy.

\section{References}

1. Nagle, R. B. (1988) Intermediate filaments: A review of basic biology. Am. J. Surg. Pathol. 12 (suppl 1), 4-16.

2. Moll, R., Franke, W. W. \& Shiller, D. L. (1982) The catalog of human cytokeratins: Patterns of expression in normal epithelia, tumors and cultured cell. Cell 31, 11-24.

3. Hatzfeld, M. \& Franke, W. W. (1985) Pair formation and promiscuity of cytokeratins: Formation in vitro of heterotypic complexes and intermediate-sized filaments by homologus and heterologous recombinations of purified polypeptides. J. Cell. Biol. 101, 1826-1841.

4. Battiflora, H. (1988) The biology of the keratins and their diagnostic applications. In: Advances in Immunohistochemistry (DeLellis, R. A., ed.) pp. 191-221, Raven Press, New York.

5. Debus, E., Moll, R., Franke, W. W., Weber, K. \& Osborne, M. (1984) Immunohistochemical distinction of human carcinomas by cytokeratin typing with monoclonal antibodies. Am. J. Pathol. 114, 121-130.

6. Weber, K., Osborn, M., Moll, R., Wiklund, B. \& Löning, B. (1984) Tissue polypeptide antigen (TPA) is related to the nonepidermal keratins 8,18 and 19 typical of simple and nonsquamous epithelia: Re-evaluation of a human tumor marker. EMBO J. 3, 2707-2714.

7. Quinlan, R. A., Schiller, D. L., Hatzfeld, M., Achtstätter, T., Moll, R., Jorcano, J. L., Magin, T. M. \& Franke, W. W. (1985) Patterns of expression and organization of cytokeratin intermediate filaments. Ann. NY Acad. Sci. 455, 282-306.

8. Björklund, B., Björklund, V., Wiklund, B., Lundström, R., Ekdahl, P. H., Hagbard, L., Kaijser, K., Eklund, G. \& Lüning, B. (1973) A human tissue polypeptide related to cancer and placenta: I. Preparation and properties; II. Assay technique; III. Clinical studies of 1483 individuals with cancer and other conditions. In: Immunological Techniques for Detection of Cancer - The Folksam Symposium, pp. 133-187, Bonniers, Stockholm, Sweden.

9. Björklund, B. (1980) On the nature and clinical use of tissue polypeptide antigen (TPA). Tumor Diagnostik $1,9-20$.

10. Lüthgens, M. \& Schlegel, G. (1980) CEA + TPA in der klinischen Tumordiagnostik, insbesondere des Mamma-Karzinoms. Tumor Diagnostik 2S, 63-77.

11. Oehr, P., Bönnen, U. \& Winkler, C. (1985) Prognostic values of TPA, CEA and their combination by product formation in

different cancer locations. In: Protides in Biological Fluids (Peeters, H., ed.) Pergamon Press, Oxford.

12. Montinari, F., Pancera, G., Merrino, M., Luporini, G., Pozzi, F., Perolini, S. \& Petrini, C. (1987) Long-term follow-up and therapy monitoring of cancer: Is the simultaneous dosage of CEA and TPA useful? In: Human tumor markers (Cimino, F., Birkmayer, G. D., Klavins, J. V., Pimental, E. \& Salvatore, F., eds.) pp. 613-619, Walter de Gruyter \& Co., Berlin.

13. Gion, M., Mione, R., Gatti, C., Dittadi, R., Leon, A. E., Nascimben, O., Pizzomo, B. \& Bruscagnin, G. (1990) Is tissue polypeptide antigen still a useful tumor marker in breast carcinoma? Comparison with CA15.3 and MCA. Tumori 76, 360-364.

14. Gion, M., Mione, R., Gatti, G., Dittadi, R., Leon, A. E., Castiglioni, C., Nascimben, O. \& Bruscagnin, G. (1990) Tissue polypeptide antigen in tumor cytosol: A new prognostic indicator in primary breast cancer. Breast Cancer Res. Treat. 17, 15-21.

15. Gion, M., Mione, R., Pappagallo, G. L., Nascimben, O., Brandes, A., Vinante, O. \& Bruscagnin, G. (1993) Tissue polypeptide antigen in breast cancer cytosol. A new effective prognostic indicator. Eur. J. Cancer 29A, 66-69.

16. Gion, M., Mione, R., Pappagallo, G. L., Gatti, C., Nascimben, O., Sampognaro, E. \& Meo, S. (1994) Biochemical parameters for prognostic evaluation in patients with breast cancer. Anticancer Research 14, 693-698.

17. Mellerick, D. M., Osborn, M. \& Weber, K. (1990) On the nature of serological tissue polypeptide antigen (TPA); monoclonal keratin 8,18 , and 19 antibodies react differently with TPA prepared from human cultured carcinoma cells and TPA in human serum. Oncogene $S, 1007-1017$.

18. Bodenmüller, H., Donié, F., Kaufmann, M. \& Banauch, D. (1994) The tumor markers TPA, TPS, TPA cyk $_{\text {and CYFRA 21- }}$ 1 react differently with the keratins 8,18 and 19 . Int. J. Biol. Mark., in press.

19. Björklund, B., Björklund, V., Grönlind; H. \& Back, M. (1987) The enigma of a human tumor marker. TPA revisited. In: $H u-$ man Tumor Markers (Cimino, F., Birkmayer, G. D., Klavins, J. V., Pimental, E., Salvatore, F., eds.) pp. 169-180, Walter de Gruyter \& Co., Berlin.

20. Björklund, B. (1992) Tumor markers TPA, TPA-S and cytokeratins. A working hypotesis. Tumordiagn. Ther. 13, 78-80. 
21. Sticber, P., Dienemann, H., Hasholzner, U., Müller, C. H., Poley, S., Hofmann, K. \& Fateh-Moghadam, A. (1993) Comparison of cytokeratin 19 fragment (CYFRA 21.1), tissue polypeptide antigen (TPA) and tissue polypeptide specific antigen (TPS) as tumour marker in lung cancer. Eur. J. Clin. Chem. Clin. Biochem. 31, 689-694.

22. Yalow, R. S. \& Berson, S. A. (1968) In: Radioisotopes in Medicine, In Vitro Studies. Oak Ridge: US Atomic Energy Commission Conference 671111 (Hayes, R. L., Goswitz, F. A., Murphy, B. E. P., eds.) pp. 22-30.

23. Ekins, E. P., Newman, G. B. \& O'Riordan, J. L. H. (1968) Aspects of "saturation" and radioimmunoassay. In: Radioisotopes in Medicine, in Vitro Studies. Oak Ridge. US Atomic Energy Commission Conference 671111 (Hayes, R. L., Goswitz, B. E., Murphy, B. E. P., eds.) pp. 84-97.

24. EORTC Breast Cancer Cooperative Group (1980) Revision of the standards for the assessment of hormone receptors in human breast cancer. Eur. J. Cancer Clin. Oncol. 16, 1513-1515.

25. Bradford, M. M. (1976) A rapid and sensitive method for the quantitation of microgram quantities of protein utilizing the principle of protein-dye binding. Analytical Biochem. 72, $248-254$.
26. Gion, M., Mione, R., Dittadi, R., Fasan, S., Pallini, A. \& Bruscagnin, G. (1986) Carcinoembryonic antigen, ferritin and tissue polypeptide antigen in serum and tissue. Cancer 57, 917-922.

27. von Kleist, S., Bombardieri, E., Buraggi, G., Gion, M., Hertel, A., Hör, G., Noujaim, A., Schwartz, M., Senekowitsch, R. \& Wittekind, C. (1993) Immunodiagnosis of tumors. Eur. J. Cancer 29A, 1622-1630.

28. Gion, M., Mione, R., Becciolini, A., Balzi, M., Correale, M., Paradiso, A., Piffanelli, A., Giovannini, G., Saccani Jotti, G. \& Fontanesi, M. (1994) Relationship between cytosol TPS, TPA and cell proliferation. Int. J. Biol. Markers, 9, 109-114.

Dr. Massimo Gion

Centro Regionale Indicatori Biochimici di Tumore Ospedale Civile

Campo SS. Giovanni e Paolo

I-30122 Venezia

Italy 


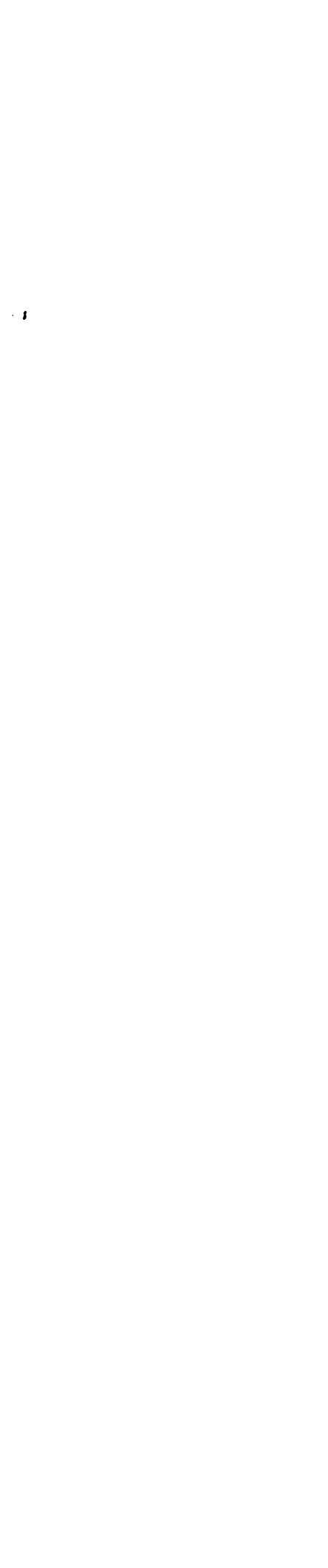

